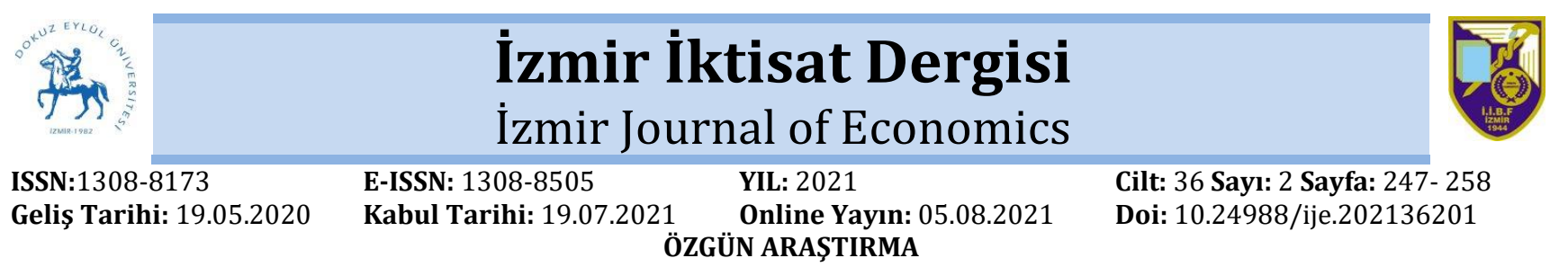

\title{
Petrol Fiyatları ile Türkiye'nin Dış Ticaret Açı̆̆ı Arasında Zamana Göre Değişen Nedensellik Analizi
}

\author{
Memduh Alper DEMÍR ${ }^{1}$ \\ Özet
}

Bu çalışmanın amacı, 1969-2018 dönemi için küresel petrol fiyatları ile Türkiye'nin dış ticaret açı̆ğı arasındaki nedenselliği tespit etmektir. Bu amaçla, Hacker ve Hatemi-J bootstrap simetrik nedensellik testi ile birlikte, literatürde kayan pencereler olarak da tanımlanan zamana göre değişen nedensellik testi uygulanmıștır. Analizler sonucunda tüm dönem için nedensellik çıkmamıştır. Ancak, zamana göre değisşen nedensellik sonuçlarına göre sadece 1998 yılında yüzde beş anlamlılık düzeyinde dış ticaret açıklarından küresel petrol fiyatlarına doğru bir nedensellik tespit edilmiştir.Bu çalışmanın konu ile ilgili literatüre yöntemsel bir katkı sağlayacaktır. Sonuçlar çerçevesinde, Türkiye'de enerji tasarrufu sağlayan politikaların uygulamalarının artması gerektiği düşünülmektedir. Bu çerçevede özellikle sanayi kesiminde alternatif enerji üretimi (güneș, rüzgar vb.) kullanılmall, elektrik ile çalışan otomobil üretimi çalışmalara hız kazandırılmalı, toplumda bireysel enerji tüketimini minimize edecek bilinç sağlanmalıdır.

Anahtar kelimeler: Dış Ticaret Açı̆̆ı, Petrol Fiyatları, Hacker ve Hatemi-J Simetrik Nedensellik, Zamana Göre Değişen Nedensellik, Kayan Pencereler

Jel Kodu: F10, F14, C32

\section{A Time-Varying Causality Analysis Between Oil Prices and Trade Deficit of Turkey}

\begin{abstract}
The purpose of this study is to determine the causality between global oil prices and the trade deficit of Turkey in the period 1969 to 2018. For this purpose, along with the Hacker and Hatemi-J bootstrap symmetric causality test, the time-varying causality test, which is also defined as rolling windows in the literature, was applied. As a result of the analysis, no causality was found for the entire period. However, according to the results of causality that changed over time, only in 1998, the causality from foreign trade deficits to global oil prices was determined at a significance level of 5 percent. This study will make a methodological contribution to the literature on the subject. In the framework of the results, the increased application of energy-saving policies is considered necessary in Turkey. In this context, alternative energy production (solar, wind, etc.) should be used, especially in the industrial sector, electricity-powered automobile production should be accelerated, and the society should be conscious about minimizing individual energy consumption.
\end{abstract}

Keywords: The foreign trade deficit, Oil Prices, Hacker and Hatemi-J Symmetric Causality, Time-varying Causality, Rolling Windows

Jel Codes: F10, F14, C32

\section{GíRiș}

Türkiye'nin ve benzeri ekonomik yapıya sahip ülkelerin ekonomide en büyük sorunlarından biri dış ticaret açıklarıdır. Dış ticaret açıklarının temel anlamda yarattığı en büyük sorun, harcamalar yöntemine göre hesaplanan milli gelir denklemi üzerinde azaltıcı etki yaratmasıdır. Dış ticaret açığının nedenleri birçok çalışmada ortaya konulmaktadır. Bu etkenlerden biri de, gerek ara ve yatırım malı olarak gerekse de nihai mal olarak kullanılan petrolün fiyatlarındaki değişimdir. Petrol günümüz dünyasında üretim sürecinde kullanılan en büyük girdilerden biridir. Ayrıca, diş ticarete en çok konu olan mallardan biri niteliği de taşımaktadır.

ATIF ÖNERİ́í (APA): Demir, M. A. (2021). Petrol fiyatları ile Türkiye'nin dış ticaret açı̆̆ı arasında zamana göre değişen nedensellik analizi. İzmir İktisat Dergisi. 36(2). 247-258. Doi: 10.24988/ije.202136201

1 Dr., Kastamonu Üniversitesi, İktisadi ve İdari Bilimler Fakültesi, İktisat Bölümü, KASTAMONU, EMAIL:mademir@kastamonu.edu.tr ORCID: 0000-0002-9926-2611 
Türkiye ve benzeri petrol bağımlısı ülkeler, petrol fiyatlarındaki ani değişimlerin etkilerini, özellikle 1970'lerde, yaşamışlardır. Ekonomi literatürüne stagflasyon, bir başka ifade ile durgunluk içinde enflasyon, kavramı 1973 ve 1979 yılları arasında yaşanan petrol krizleri ile geçmiştir. Petrol bağımlısı ülkelerde bu süreç ekonomik kriz ortamı oluşturmuştur.

Petrol fiyatlarının hızlı artışı ile petrol üreticisi ülkeler kazançlarını arttırırken, Türkiye gibi petrol ithalatçısı ülkeler üretim kapasitesi düşüşleri, işsizlik, yetersiz ekonomik büyüme ile birlikte oluşan enflasyon süreci sonucunda stagflasyon krizine yakalanmışlardır (Demir, 2019: 37). Bunun, petrol fiyatlarındaki ani değişimlerin ülke ekonomileri üzerinde yaratabileceği etkileri gösteren tarihteki en büyük emtia kaynaklı kriz olduğu, birçok araștırmacı tarafından ortaya konulmaktadır.

Petrol fiyatlarında oluşan artış yönlü bir şok petrol ithalatçısı ülkeler için bir ticaret haddi şokudur. Böyle bir şok petrolün önemli bir üretim girdisi olmasından dolayı ekonominin üretim kararlarını etkileyen bir problem olarak düşünülmektedir. Dolayısıyla, bu üretimdeki girdinin fiyatlarındaki artış aynı anda ticaret dengesi üzerinde bozucu etki yaratmaktadır. Petrol fiyatındaki artışın üretim veya arz üzerindeki etkisinden farklı olarak, talep üzerine de etkisi olmaktadır. Petrol fiyatlarındaki artış başka mallara olan talebi, bir başka ifade ile diğer malların tüketici bütçesinden aldığı payları yani harcama miktarlarını azaltacaktır. Bu durumda, esas olarak, petrol talebinin fiyat esnekliği ile alakalı olarak, bu esnekliğin düşük olduğu varsayımından yola çıkılarak, petrol fiyatlarındaki artıştan dolayı ithal ve ihraç edilen mal miktarının değiștiği, bunun sonucu olarak da ticaret dengesinin bozulduğu belirtilmektedir. (Bayat, Şahbaz ve Akçacı, 2013: 70-71).

Petrolün fiyatındaki değişimlerin dış ticaret dengesi üzerindeki etkisinin tespit edilmesi iktisat politikası karar birimleri açısından önemlidir. Bernanke, Gertler ve Watson (1997) petrol fiyatlarındaki bir artışın para politikası müdahaleleri ile ekonomi üzerindeki durgunluk baskısını arttırdığını ortaya koymaktadır. Durgunluk baskısı ekonomide dış ticaret dengesi üzerinde ylkıcl etki yaratmaktadır. Petrol fiyatlarının bu şekilde ekonominin cari dengesi üzerinde etkili oluşuna parasal kanal denilmektedir. Petrolün fiyatındaki artışın ithal ve ihraç edilmekte olan ürünlerin fiyat ve miktarlarını değiştirmesi vasıtası ile diş ticaret dengesini değiştirmesine ise ticaret kanalı denilmektedir. Petrol fiyatlarındaki değişimlerin petrol ihracatçısı ülkelerin sahip olduğu varlıkların fiyatlarının ve karlılıklarının artacağı ve bu sayede refah artışı sağlanıp oluşan refahın bir bölümünün petrol ithalatçısı ülkelere transfer edilmesi ile cari dengede sermayenin transferlerinin sonucu olarak değişim yaşanacağ belirtilmektedir. $\mathrm{Bu}$ duruma da finansman kanalı ismi verilmektedir (Bayat ve diğerleri, 2013: 71).

Bu çalışmanın amacl, 1969-2018 dönemi için küresel petrol fiyatları ile Türkiye'nin diş ticaret açığı arasındaki nedenselliğin tespitinin, zamana göre değişen nedensellik testi ile incelenmesidir. Ayrıca, literatür incelendiğinde, konu ile ilgili zamana göre değișen nedensellik testlerinin kullanımına rastlanılmaması, bu çalışmayı yöntem açısından diğer çalışmalardan ayırmaktadır.

Söz konusu amaç çerçevesinde çalışmada ilk olarak, petrol fiyatlarının diş ticaret ve cari denge üzerinde etkisinin nasıl oluştuğu ile ilgili teorik çerçeve ortaya konulmuştur. Türkiye'nin dış ticaret açığı ile küresel petrol fiyatları arasındaki ilișkinin zamana göre değișen nedensellik testi ile analiz edildiği bu çalıșmanın bir sonraki bölümünde, Türkiye ile ilgili yapılan çalışmalar ve bu çalışmayı diğer çalışmalardan ayıran farkı ortaya koyan literatür taraması yapılmaktadır. Ayrıca literatür taramasında, ele alınan ilişkiyi zamana göre değişen nedensellik testi ile inceleyen diğer ülke çalışmaları da ortaya konulmuştur. Çalışmanın üçüncü bölümü ekonometrik yöntemi, dördüncü bölümü ise ampirik bulguları ortaya koymaktadır. Çalışma politika 
önerilerinin sunulduğu sonuç bölümü ile tamamlanmıştır.

\section{LITERATÜR TARAMASI}

Türkiye'nin dış ticaret açığı ile küresel petrol fiyatları arasındaki ilişkiyi inceleyen bu çalıșmaya benzer olan petrol fiyatları ile cari açık arasındaki ilişkiyi de dikkate alan çalışmalar literatürde yer almaktadır. Bu çalışmaların yöntemleri incelendiğinde, nedensellik çalışmaları dışında diğer yöntemleri içeren çalışmaların da olduğu görülmektedir. Ayrıca, bazı çalışmalar hem nedensellik hem de başka bir teknik kullanılarak yapılmıştır. Bu çerçevede, söz konusu ilişkiyi ortaya koyan çalışmalar incelenmektedir. Ancak, anılan çalışmalar eğer nedensellik ve başka bir yöntem içeriyorsa, sadece nedensellik sonuçları, çalışmamızla karşılaştırılması açısından dikkate alınmıştır.

Ele alınan çalışmaların bir kısmı analiz olarak Granger-Nedensellik testini kullanmaktadır. Bu çalışmalar içerisinde Başarır ve Erçakar (2016) petrol fiyatları ile cari açı arasında çift yönlü nedensellik bulmuştur. Değirmen ve Saltık (2017) petrol fiyatlarındaki oynaklıktan dış ticaret dengesine doğru nedenselliği tespit etmiştir. Afşar, Cura ve Mıhoğlu (2019) petrol fiyatından cari açığa doğru bir nedensellik tespit ederken, Bayar, Kılıç ve Arıca (2014) petrol fiyatları ile cari açı arasında nedenselliğin olmadığını belirtmişlerdir.

Doğrusal olmayan nedensellik testleri ile de bu konu araştırılmıştır. Doğan ve Gürbüz (2017) çalışmalarında enerji giderleri ile dış ticaret açığı arasında çift yönlü nedensellik tespit etmiștir. Bayat ve diğerleri (2013) ise doğrusal olmayan nedensellik ile birlikte frekans alanı nedensellik yöntemini de kullanmıştır. Doğrusal olmayan nedensellik sonuçlarına göre petrol fiyatlarından dıș ticaret açığına doğru doğrusal olmayan nedenselliği tespit ederken, frekans alanı nedenselliğe göre de aynı yönde nedenselliği tespit etmiștir. Ancak, bu nedensellik orta vadede görülmekte ve uzun vadede kaybolmaktadır.
Bu konu üzerine yapılan çalıșmalar arasında, Toda-Yamamato nedensellik analizini kullananlar diğerlerine göre daha çoktur. Beșel (2017), Karadaş, Salihoğlu ve Koşaroğlu (2019) petrolün fiyatından cari dengeye doğru nedensellik tespit etmiştir. Polat (2019) çalışmasında petrol fiyatları ile dış ticaret dengesi arasında nedenselliğin olmadığı sonucuna ulaşmıştır. Bayar ve Karamelikli (2015) ise, hem petrol hem de doğalgaz fiyatından dış ticaret dengesine doğru bir nedensellik tespit etmişlerdir.

Lebe ve Akbaş (2015) petrol fiyatından cari açığa doğru nedenselliği Dolado ve Lutkepohl nedensellik testi ile bulmuştur. Bayraktar, Eğri ve Ylldız (2016) ise, Türkiye'nin de yer aldığg kırılgan beşli ülkeler için yaptıkları panel Granger nedensellik sonuçlarına göre petrolün fiyatından cari işlemler açığına doğru nedensellik tespit etmişlerdir.

Bu çalışmaya en yakın çalışma ise Kırca ve Karagöl (2019) tarafından gerçekleştirilmiştir. Araştırmacılar ilk olarak, bu çalışmada da kullanılan Hacker ve Hatemi-J simetrik nedensellik testini kullanmışlardır. Test sonucuna göre petrol fiyatından cari dengeye doğru nedensellik tespit edilmiştir. Ancak, bu çalışmada yer alan zamana göre değişen nedensellik yöntemi kullanılmamıştır. Ayrıca, Kırca ve Karagöl (2019) Hatemi-J asimetrik nedensellik yöntemini uygulamışlar ve sonuçlara göre, negatif petrol fiyatı şoklarından hem negatif cari denge şoklarına ve hem de pozitif cari denge şoklarına doğru nedensellik tespit etmişlerdir.

Literatürde konu ile ilgili Türkiye için nedensellik analizleri dışında diğer yöntemler ile gerçekleştirilen analizler de mevcuttur. Erdoğan ve Bozkurt (2009) MGARCH yöntemi ile petrol fiyatlarındaki artışın cari açığı arttırdığını tespit etmişlerdir. Bozgeyik ve Kutlu (2019) MV-GARCH tekniği ile petrol fiyatları ve cari işlemler açığı arasında negatif yönlü ilişki tespit ederken, Güngör, Sönmez, Korkmaz ve Karaca (2016) da ARCH-GARCH yöntemleri ile aynı sonuca ulaşmışlardır. Özlale ve Pekkurnaz (2010) oluşturdukları Yapısal 
VAR analizi ile cari ișlemler açığının petrol fiyatlarına verdiği tepkilerin geçici olduğunu ortaya koyarken, Açıkalın ve Uğurlu (2014) aynı yöntemle yaptıkları çalışmalarında petrol fiyatı şoklarının dış ticaret dengesi üzerinde negatif etki yarattığını belirtmişlerdir. Göçer, Deniz ve Bursal (2019) yaptıkları Maki eşbütünleşme analizi sonucu ithalat ile petrol fiyatları ve ihracat ile petrol fiyatları arasında eş-bütünleşik ilişki bulamamışlardır. İnsel ve Kayıkçı (2013) ise, ARDL tekniği kullanarak petrol fiyatlarındaki artışın cari açığ kötüleștirdiği sonucuna ulașmıșlardır. Kadooğlu Aydın (2017) 2014-2015-2016 yılları açısından klasik regresyon analizi ile yaptığı çalışmada petrol fiyatları ile cari açık arasında en güçlü ilişkinin 2014 yılında çıktığını belirtmiştir. Knight, Nedeljkovic ve PortugalPerez (2019) Jacknife Model Ortalaması (JMA) tahmincisi ile yaptıkları çalışmada petrol fiyatlarının cari açı̆̆ı negatif etkilediği sonucuna varmışlardır. Unutur (2018) Johansen Eşbütünleşme analizi sonuçlarına dayalı olarak petrol fiyatlarındaki artışın dış ticaret açığını arttırdığını bulmuştur. Son olarak, Terzi ve Çelik (2016) ise, yaptıkları dalgalı sürekli dönüşüm analizi ile özellikle kriz ve dalgalanma dönemlerinde petrol fiyatlarının dış ticaret açığına neden olduğunu belirtmektedirler.

Türkiye ile ilgili çalışmalar incelendiğinde, petrol fiyatları ile dış ticaret açıkları arasındaki nedenselliği zamana göre değișen nedensellik yöntemi ile inceleyen çalışmaya rastlanılmamıştır. Uluslararası literatürde de zamana göre değișen nedensellik analizleri teknikleri ile petrol fiyatları ve diş ticaret açıkları arasındaki nedenselliği açıklayan çalışmaya rastlanılmamakla birlikte, farklı nedensellik yaklaşımları ile bu ilişkiyi farklı ülkeler düzleminde inceleyen çalışmalar mevcuttur.

Le ve Chang (2013) Japonya, Singapur ve Malezya için yaptıkları çalışmada, tek yönlü nedensellik olarak petrol fiyatlarından ülkelerin toplam dış ticaret dengesine (ayrıca bu dengeyi ikiye ayırıp petrol ticareti dengesi yanında, petrol dişındaki mallar dengesini de incelmişlerdir) doğru nedenselliği TodoYamamoto nedensellik testi ile incelemişlerdir. Japonya'da ve Singapur'da nedensellik ilişkisi yokken, Malezya'da nedensellik çıkmıştır.

Rafiq, Salim ve Bloch (2009) Tayland'da Granger nedensellik sonuçlarına göre petrol fiyatlarındaki oynaklıktan dış ticaret dengesine doğru tek yönlü nedensellik bulmuşlardır.

Abuoliem, Nor, Matar ve Hallahan (2019) Ürdün'de Granger nedensellik sonuçlarına göre petrol fiyatlarından dış ticaret dengesine doğru tek yönlü nedensellik olduğunu tespit etmişlerdir.

Olayungbo (2019) Nijerya'da BreitungCalderon tarzl frekans temelli Granger nedensellik sonuçlarına göre petrol fiyatları ile dış ticaret dengesi arasında nedensellik tespit etmemişlerdir. Kunle (2020) Nijerya'da Granger nedensellik sonuçlarına göre petrol fiyatlarındaki oynaklıktan dış ticaret dengesine doğru tek yönlü nedensellik sonucuna varmışlardır.

Boman (2019)'ın Norveç ve İsveç için petrol fiyatları ile dış ticaret dengesi arasındaki nedenselliği incelediği çalışmasında, Granger nedensellik sonuçlarına göre İsveç'te nedensellik ilişkisi çıkmamışken, Norveç'te petrol fiyatlarından dış ticaret dengesine doğru nedensellik görülmüştür.

Tiwari, Arouri ve Teulon (2014) Hindistan'da Breitung-Calderon tarzı frekans temelli Granger nedensellik sonuçlarına göre petrol fiyatları ile dış ticaret dengesi arasında çift yönlü nedensellik tespit etmişlerdir.

Türkiye ve diğer ülkelerle ilgili literatür dikkate alındığında, bu çalışmayı diğer çalışmalardan ayıran nokta ise, zamana göre değişen nedensellik yönteminin kullanılması ve dolayısıyla yöntemsel farklılığın olmasıdır.

Nedensellik ilişskisinin tespiti için literatürde birçok test mevcuttur. Bu testlerin bir kısmında da Granger nedensellik testinin bootstrap kritik değerleri üretilmiştir. Bunlardan biri de bu makalede kullanılan Toda-Yamamoto 
nedensellik testinin bootstrap versiyonudur. Toda-Yamamoto nedensellik testleri çeşitli avantajlara sahiptir. Analizdeki değişkenler arasında eşbütünleşik ilişkinin varlığı veya yokluğu önemli olmamaktadır. Ayrıca, Granger(1996) yapısal istikrarsızlığın günümüzde araştırmacıların karşı karşıya olduğu en önemli sorun olduğunu belirtmiştir. Balcılar, Özdemir ve Arslantürk (2010) yapısal değişiklikler probleminin ve nedensellik öncesi ön-testlerin fazlaca yapılması önyargısını minimize etmek için modifiye edilmiş bootstrap testine dayanan kayan pencere granger nedensellik testini kullanmaktadır. Yapısal değişiklikler parametrelerde kaymalara neden olabilmekte ve nedensellik ilişkisinin modeli zamanla değişebilmektedir. Yapısal değişiklikler ve sabit olmayan parametrelerle başa çıkmak için, tam örneğe ek olarak, bootstrap nedensellik testi kayan pencere alt örneklerine de uygulanmaktadır (Balcılar ve diğerleri, 2010: 1400). Özetle çeşitli avantajları Balcılar ve diğerleri (2010) tarafindan ortaya konulan bootstrap TodaYamamoto zamana göre değişen (kayan pencereler) nedensellik testinin uygulanması, bu çalışmayı konu ile ilgili diğer çalışmalardan ayıran noktadır.

\section{EKONOMETRÍK METODOLOJİ}

Çalışmada ilk olarak, serilerin durağanlığını incelemek için birim kök testleri uygulanmış, sonrasinda sirasıyla Hacker ve Hatemi-J (2006) Bootstrap simetrik nedensellik testi ve zamanla değişen nedensellik testi uygulanarak Türkiye'de küresel enerji fiyatları ile dıș ticaret açığı arasındaki nedensellik incelenmiştir. $\mathrm{Bu}$ çerçevede sırasıyla, uygulanan birim kök testleri ve nedensellik testlerinin ekonometrik metodolojisi ortaya konulmuştur.

\subsection{Birim kök testleri}

Zaman serilerinde durağanlık problemi, yapılan çalışmalarda tatmin edici sonuç çıkmamasına yol açmaktadır. Dolayısıyla iktisat yazınında durağanlık sınaması için, bağımlı değişkenlerin gecikmeli değerlerini modele bağımsız değişken olarak ilave edip otokorelasyonu gideren genişletilmiş Dickey-
Fuller (1981) (Augmented Dickey Fuller (ADF)) birim kök testi ve zaman serilerindeki yüksek derecedeki korelasyonu kontrol etmek için parametrik olmayan bir yöntem oluşturan Philips ve Perron (PP) (1988) testi geliştirilmiştir.

Yapısal kırılmaların etkisini dikkate almadan yapılan birim kök testlerinden elde edilen sonuçlar sapmalı olabilmektedir (Kolçak, Kalabak ve Boran, 2017: 474). Çalışmada ele alınan dönem çok sayıda yapısal kırılmanın ve rejim değişimlerinin olduğu yılları kapsamaktadır. Dolayısıyla yapısal kırılmaların etkisini dikkate alan Lee-Strazicich (2003) birim kök testi sonucu ortaya konulmuştur.

Lee ve Strazicich (2003) tarafından geliştirilen LM birim kök testi hem boş hipotez hem de alternatif hipotez altında kırılmalara izin vermektedir. Ayrıca söz konusu test iki adet içsel kırılmanın varlığını ortaya koymaktadır.

\subsection{Hacker ve Hatemi-J bootstrap simetrik nedensellik testi}

Hacker ve Hatemi-J (2006)'nin oluşturduğu bootstrap simetrik nedensellik testi, TodaYamamoto (TY) (1995) nedensellik testine dayanarak değişkenler arasında eş-bütünleşik ilişkinin varlığını zorunlu tutmamaktadır. Ayrıca, analizdeki değişkenler eğer farklı durağanlık derecelerine sahip ise, bu test yapılabilmektedir. Hacker ve Hatemi-J (2006), TY (1995) testinin bootstrap versiyonu olarak da tanımlanmakta, yani TY'den farklı olarak analizi bootstrap kullanarak yenilemektedir. Bilindiği üzere TY (1995) testinde değişkenlerin esas değerleri, bir başka ifade ile düzey değerleri ile analizler yapılabilmektedir. Hacker ve Hatemi- J testide aynen TY (1995) testi gibi değişkenlerin düzey değerlerinde modelde yer almasına imkân veren VAR $(k+d \max )$ modeline dayanan bir nedensellik testidir. TY ve Hacker ve Hatemi-J testleri, değişkenlerin seviye değerlerine optimal gecikme uzunluğunun $(k)$ yanı sıra maksimum durağanlık mertebesinin ( $d$ max) eklenmesiyle oluşan VAR modelinde $\chi 2$ dağılımına sahiptir. İşte TY (1995) için de ortaya konulmakta olan 
bu süreçler Hacker ve Hatemi-J (2006) nedensellik testi için de geçerli olmaktadır. Hacker ve Hatemi-J (2006) Wald istatistiğinde bazı değişimler oluşturarak M-Wald istatistiğini elde etmiştir. Hesaplanan MWald istatistik değeri de $\chi 2$ dağılımı sergilemektedir. Hacker ve Hatemi-j (2006) bazı durumlarda modelde değișen varyans sorunu olduğunu ortaya koymakta ve bootstrap yöntemi kullanarak bu sorunu ortadan kaldırmakta ve geliştirdikleri teste ait kritik değerleri de boostrap yöntemiyle oluşturmaktadırlar. Dolayısıyla bu yöntem diğer simetrik nedensellik testlerinden üstün hale gelmektedir. Analiz sonucunda hesaplanan Hacker ve Hatemi-j(2006) test istatistik değeri eğer bootstrap kritik değerlerinden büyük ise değişkenler arasında nedensellik ilişkisi tespit edilmektedir. Aksi durumunda da değişkenler arasında nedensellik ilişkisi yoktur. (Karagöl ve Kırca, 2019: 6; Yılmaz ve Tütüncü, 2020:53).

\subsection{Kayan pencereler nedensellik testi (Zamana göre değişen nedensellik testi)}

Balcılar ve diğerleri (2010) tarafından geliştirilen bu testte, kalıntı temelli bootstrap tekniği(RB) ve düzeltilmiş LR (likelihood-ratio) testi kullanılarak enerji tüketimi ile reel GSYIH (Gayrisafi yurtiçi Hasıla) arasındaki nedensellik ilişkisi incelenmiştir.

Bootstrap LR Granger nedenselliğini göstermek için iki değişkenli VAR (p) süreci şu şekilde ifade edilir:

$$
\begin{aligned}
& y t=\Phi 0+\Phi 1 y t-1+\ldots+\Phi p y t-p+ \\
& \varepsilon t \quad t=1 ; 2 ; \ldots ; T
\end{aligned}
$$

Eşitlik 1 'de $\varepsilon t=\left(\varepsilon_{1} t, \varepsilon_{2} \mathrm{t}\right)$ tekil olmayan kovaryans matrisi $(\Sigma)$ ile birlikte sıfır ortalamalı bağımsız beyaz gürültü (ortalaması ve sabit varyansı olmayan rassal değişkenler) sürecidir. Burada p değeri bilinmektedir. Gecikme uzunlukları da Akaike Bilgi Kriteri (AIC) kullanılarak belirlenmektedir. Balcılar vd. (2010) yt vektörünü çalışmalarında kullandıkları enerji tüketimi $\left(\mathrm{y}_{1 \mathrm{t}}\right)$ ve reel GSYİH (y2t) olmak üzere iki ayrı vektöre ayırmışlar ve Eşitlik 1'i yeniden oluşturmuşlardır. $\begin{array}{ll}y_{1 t} \\ y_{2 t}\end{array}=\begin{array}{ll}\Phi_{10} \\ \Phi_{20}\end{array}+\begin{array}{ll}\Phi_{11}(L) & \Phi_{12}(L) \\ \Phi_{21}(L) & \Phi_{22}(L)\end{array} * \begin{aligned} & y_{1 t} \\ & y_{2 t}\end{aligned}+\frac{\varepsilon_{1 t}}{\varepsilon_{2 t}}$

Burada $\Phi_{i j}(L)=\sum_{k=1}^{p} \Phi_{i j k} L^{k}, \quad \mathrm{i}, \mathrm{j}=1,2$ ve $\mathrm{L}$ gecikme operatörü ( $\left(\mathrm{L}^{\mathrm{k}} \mathrm{Xt}_{\mathrm{t}}=\mathrm{c}-\mathrm{X}_{\mathrm{t}-\mathrm{k}}\right)$ olarak tanımlanmaktadır. Bu çerçevede boş hipotez GSYİH'nin enerji tüketiminin Granger nedeni olmadığıdır ve sıfır kısıt $\left(\Phi_{12 i}=0\right.$ ve $i=$ $1,2, \ldots p)$ altında test edilebilmektedir. Benzer şekilde de boş hipotez enerji tüketimi GSYİH'nin Granger nedeni olmadığıdır ve sıfır kısit $\left(\Phi_{21 i}=0\right.$ ve $\left.i=1,2, \ldots p\right)$ altında test edilebilmektedir (Balcılar ve diğerleri, 2010: 1400).

Eşitlik 2'deki nedensellik ilişkisinin tespiti için literatürde birçok test mevcuttur. Bu testlerin bir kısminda da Granger nedensellik testinin bootstrap kritik değerleri üretilmiştir. Bunlardan biri de Balcılar ve diğerleri(2010) tarafindan kullanılan Toda-Yamamoto nedensellik testinin bootstrap versiyonudur. Toda-Yamamoto nedensellik testleri çeşitli avantajlara sahiptir. Analizdeki değişkenler arasında eşbütünleşik ilişkinin varlığı veya yokluğu önemli olmamaktadır. Ayrıca, Granger(1996) yapısal istikrarsızlığın günümüzde araştırmacıların karşı karşıya olduğu en önemli sorun olduğunu belirtmiştir. Balcılar ve diğerleri (2010) yapısal değişiklikler probleminin ve nedensellik öncesi ön-testlerin fazlaca yapılması önyargısını minimize etmek için modifiye edilmiş bootstrap testine dayanan kayan pencere granger nedensellik testini kullanmaktadırlar. Yapısal değişiklikler parametrelerde kaymalara neden olabilmekte ve nedensellik ilişkisinin modeli zamanla değișebilmektedir. Yapısal değișiklikler ve sabit olmayan parametrelerle başa çıkmak için, tam örneğe ek olarak, bootstrap nedensellik testi kayan pencere alt örneklerine de uygulanmaktadır (Balcılar ve diğerleri, 2010:1400).

Bir zaman serisinde zamanla değişen etkiyi ölçmek amacıyla kayan pencere yöntemi kullanılmaktadır. Bu yöntem ile analize konu olan dönemin ilk senesinden başlayarak belirlenmiş olan pencere uzunluğu büyüklügünde alt örneklemler oluşturulmakta 
ve verinin frekansı $(m)$ ve pencere boyutu $(l)$ arasındaki fark $(m-l)$ kadar alt örneklem sayısı oluşmaktadır. $\mathrm{Bu}$ sayede, her bir pencere uzunluğuna VAR modeline dayanan bootstrap nedensellik testi uygulanarak nedensellik sonuçlarının dönem içerisinde değișmesine olanak tanınmaktadır (Yılmaz ve Tütüncü, 2020:54; Balcllar ve diğerleri, 2010: 1400). Literatürde kayan pencere de denilen bu yöntem aslında zamana göre değişen nedensellik olarak da tanımlanmaktadır.

Literatürde pencere boyutunun tespitinde kesin bir kriter bulunmamakla birlikte Pesaran ve Timmermann (2005)'ın çalışmalarında elde ettiği bulgular, optimal pencere boyutunun, kırılma sayısına ve kırılmaların kalıcılığına bağlı olduğunu belirtmektedirler. Monte Carlo simülasyonları sık kırılmalar durumunda otoregresif parametrelerdeki sapmayı yaklaşıı 10-20 pencere boyutunun minimize ettiğini göstermektedir. Optimal pencere boyutunun seçimi iki farklı görüșe dayanmakta ve bunlardan ilki, tahminin serbestlik derecesi parametrelerin doğru tahmin edilebileceği kadar büyük olmasını gerektirirken, ikincisi ise birden çok yapısal kırılmanın varlı potansiyelinin, pencere boyutu aracılı̆̆ ile elde edilen küçük alt örneklemler sayesinde azaltılacak olmasıdır (Balcılar ve diğerleri, 2010: 1403; Yılmaz ve Tütüncü, 2020:54). Sonuç olarak, özellikle ylllık ve 40-50 gözlem sayısı içeren çalışmalarda pencere sayısının 1520 bandında seçildiği gözlenmektedir.

\section{AMPIRIKK BULGULAR}

Türkiye'de küresel petrol fiyatları ile dış ticaret açığı arasındaki nedenselliğin incelendiği bu çalıșmada, 1969-2018 dönemi yıllık verileri dikkate alınmıștır. Calıșmada, kullanılan küresel petrol fiyatları (KPF) serisi British Petrolum (İngiliz Petrol)'nin Enerji Üretimi ve Tüketimi veri tabanından 1861 sonrası için oluşturduğu ham petrol fiyatlarından (cari dolar cinsinden) alınmıștır ${ }^{1}$. Dış Ticaret Açıkları
(DTA) değişkeni ise TUIK dıș ticaret istatistikleri veri tabanından Türkiye'nin cari dolar cinsinden ihracat ve ithalat verilerinin birbirinden çıkarılıp mutlak değerlerinin alınması ile elde edilmiștir. Yapılan analiz kodları negatif değerleri hesaba katamadığından mutlak değer olarak alınmıştır. Türkiye'nin söz konusu yıllar içerisinde hiçbir dönemde dış ticaret fazlası vermemesi, verinin mutlak değer içerisine alınmasını kolaylaştırmıştır. Bir sene dahi dış ticaret fazlası veren bir ülke olsa bu durum sorun teşkil edebilecektir. Ancak, değer açısından dış ticaret açığının artması veya azalması da bu durumda takip edilmektedir. Bhatta (2013) çalışmasında ticaret açı̆̆ının, negatif bir ticaret dengesi olduğunu yani ihracat-ithalatın mutlak değeri olduğunu belirtirken, Yllmaz ve Bugay Tekgül (2019) ise Türkiye için dış ticaret açığını hesaplarken ithalat- ihracat şeklinde işlem yaparak pozitif değer elde edip bu değerin doğal logaritmasını almaktadır. Bir başka ifade ile örnek vermek gerekirse dış ticaret açığı veren bir ülkede 200 milyar dolar ihracat, 300 milyar dolar ithalat yapıldığını düşündüğümüzde, ihracat değerinin ithalat değerinden çıkarılıp mutlak değer içine alınması durumunda bu ülkede 100 milyar dolarlık dış ticaret açığı olacaktır. İthalat değerinden ihracat değeri çıkarıldığında da 100 milyar dolarlık dış ticaret açı̆̆ı olacaktır.

Tablo 1: ADF ve PP birim kök testi sonuçları

\begin{tabular}{|l|l|l|l|l|}
\hline ADF BIRIM KÖK TESTI SONUÇLARI \\
\hline DEĞISSKENLER & DÜZEYDE & \multicolumn{1}{l|}{$\begin{array}{l}\text { BIRINCI } \\
\text { FARKINDA }\end{array}$} \\
\cline { 2 - 5 } & SABİTLİ & $\begin{array}{l}\text { SABİT + } \\
\text { TRENDLİ }\end{array}$ & SABITLİ & $\begin{array}{l}\text { SABİT + } \\
\text { TRENDLİ }\end{array}$ \\
\hline KPF & -1.401 & -2.209 & -6.105 & -6.031 \\
\hline DTA & -1.325 & -2.734 & -8.429 & -8.329 \\
\hline PP BİRIM KÖK TESTİ SONUÇLARI \\
\hline KPF & -1.435 & -2.379 & -6.055 & -5.976 \\
\hline DTA & -1.119 & -2.654 & -8.612 & -8.506 \\
\hline
\end{tabular}

Not: Kritik Değerler Mc. Kinnon kritik değerleridir. Mc. Kinnon Kritik değerleri sırasıyla \%5 anlamlılık düzeyinde sabitte 2.922, sabit+trendde -3.504 'dir. $\% 1$ anlamlılık düzeyinde sabitte -3.571 , sabit+trendde -4.156 'dir. Gecikme sayısı 3 alınmıştır. 
$\mathrm{Bu}$ nedensellik yöntemlerinin uygulanabilmesi için değişkenlerin durağanlık seviyesinin tespiti gerekmektedir. Değişkenlerin durağanlığı ADF ve PP birim kök testleri ile yapılmış ve sonuçlar Tablo 1'de gösterilmiştir.

Yapısal kırılmalar çerçevesinde birim kökün varlığını tespit eden Lee Strazicich (LS) birim kök testi sonuçları Tablo 2'de verilmiştir.

Tablo 2: LS birim kök testi sonuçları

\begin{tabular}{|c|c|c|c|c|c|c|}
\hline \multirow[b]{2}{*}{$\begin{array}{l}\text { Değişke } \\
n\end{array}$} & \multicolumn{3}{|c|}{ Model A } & \multicolumn{3}{|c|}{ Model C } \\
\hline & $\begin{array}{l}\text { Kırılm } \\
\text { a } \\
\text { Tarihi }\end{array}$ & $\begin{array}{l}\mathrm{t}- \\
\text { istatisti } \\
\mathrm{k}\end{array}$ & $\mathrm{k}$ & $\begin{array}{l}\text { Kırılm } \\
\text { a } \\
\text { Tarihi }\end{array}$ & $\begin{array}{l}\mathrm{t}- \\
\text { istatisti } \\
\mathrm{k}\end{array}$ & $\mathrm{k}$ \\
\hline DTA & $\begin{array}{l}2000 \\
2012 \\
\end{array}$ & $-2.802^{*}$ & 6 & $\begin{array}{l}1999 \\
2008 \\
\end{array}$ & $\begin{array}{l}- \\
8.8091\end{array}$ & 4 \\
\hline KPF & $\begin{array}{l}1999 \\
2010\end{array}$ & $-3.773^{*}$ & 6 & $\begin{array}{l}1995 \\
2008\end{array}$ & $-4.226^{*}$ & 4 \\
\hline
\end{tabular}

Not: Tabloda Model A ortalamadaki kırılmayı; Model C ise ortalama ve eğimdeki (rejim) kırılmaları göstermektedir. Model A için kritik değerler $\% 1, \% 5$ ve \%10 anlamlılık düzeyinde sırasıyla $-4.54,-3.84,-3.50$ 'dir. Model C için kritik değerler kritik değerler birinci ve ikinci kırılma noktalarının kesişiminden oluşup her iki değişken için de $\% 1, \% 5$ ve $\% 10$ anlamlılık düzeyinde sirasıyla $-6.32,-5.73,-5.32$ 'dir. $\mathrm{k}$ değeri ise gecikme uzunluğudur. *, **, ve $* * *$ sirasiyla $\% 1, \% 5$ ve $\% 10$ anlamlılık düzeylerini göstermektedir.

LS birim kök testinin $\mathrm{H}_{0}$ hipotezi yapısal kırılmalar altında birim kök vardır şeklindedir. Bulunan t-istatistik değeri kritik değerden büyük olduğunda $\mathrm{H}_{0}$ hipotezi kabul edilmektedir. Bir bașka ifade ile mutlak değer içinde $\% 1$ anlamlılık düzeyinde hesaplanan test istatistikleri kritik değerlerden küçük olduğunda da $\mathrm{H}_{0}$ hipotezi kabul edilmektedir. Dolayısıyla LS birim kök testi sonuçlarına göre model C'deki DTA değişkeni dışındaki tüm değişkenler birim kök içermektedir. Ancak, ortalamada kırılmalar dikkate alındığında tüm değişkenler birim kök içermektedir.

ADF, PP ve LS birim kök test sonuçlarına göre her iki değişken birim kök içermekte, yani I (1) seviyesinde durağan olduğu görülmektedir. Bu durumda, çalışmada değişkenler arasındaki ilişkiyi analiz etmek amacıyla kullanılan nedensellik testleri VAR $\left(k+d_{\max }\right)$ modeline dayandığ için $d_{\max }=1$ olarak belirlenmiştir.
Tablo 3'de yer alan Hacker ve Hatemi-J (2006) bootstrap nedensellik testi sonuçlarına göre, test istatistik değeri kritik değerlerden küçük olduğu için küresel petrol fiyatlarından dış ticaret açığına ve dış ticaret açı̆̆ından küresel petrol fiyatlarına doğru nedensellik çıkmamıștır. Bir başka ifade ile küresel petrol fiyatları ile dış ticaret açığı arasında nedensellik ilişkisi çıkmamıştır. Hacker ve Hatemi-J (2006) Bootstrap nedensellik testinde elde edilen bulgular; Bayar ve diğerleri (2014), Polat (2019) çalıșmalarını desteklemekte, yani petrol fiyatları ile dış ticaret ve/veya cari açık arasında nedensellik olmadığını ortaya koyan sonuçlar ile örtüşmektedir.

Tablo 3: Hacker ve Hatemi-J (2006) bootstrap nedensellik testi sonuçları

\begin{tabular}{|c|c|c|c|c|}
\hline \multirow{2}{*}{$\begin{array}{c}\text { NEDENSELLIĞİIN } \\
\text { YÖNÜ }\end{array}$} & TEST & \multicolumn{3}{|c|}{ KRITİK } \\
& ISTATISTIĞ & \multicolumn{2}{|c|}{ DE ĞERLER } \\
\cline { 3 - 5 } & & $\% 1$ & $\% 5$ & $\% 10$ \\
\hline KPF $\rightarrow$ DTA & 0.425 & 11.55 & 6.80 & 5.13 \\
\hline DTA $\rightarrow$ KPF & 3.675 & 11.00 & 6.66 & 4.95 \\
\hline
\end{tabular}

Not: Analiz ve kritik değerlerin elde edilişi için 10000 bootstrap değeri kullanılarak, gecikme uzunluğu maksimum 4 ve SBC kriteri dikkate alınarak hesaplanmıştır.

Değişkenler arasında kayan pencereler yöntemi ile zamanla değişen etkiyi ölçmek amacıyla kullanılan zamanla değișen nedensellik testinin sonuçları Şekil 1'de gösterilmektedir. Analiz için 10000 bootstrap değeri, maksimum 4 gecikme uzunluğunda SBC kriteri yardımıyla optimal gecikme uzunluğu hesaplanmiştır.

1969-2018 dönemi için küresel petrol fiyatlarından dış ticaret açı̆̆ına doğru zamanla değişen nedensellik testi kullanılarak yapılan analizde, 15 sabit pencere boyutu dikkate alınarak, 35 alt dönem elde edilmiştir.

Kayan pencere tahmininde pencere boyutunu seçmek için kesin bir kriter yoktur. Ayrıca, Pesaran ve Timmermann (2015)'ın yaptıkları Monte Carlo simülasyonları sık kırılmalar durumunda otoregresif parametrelerdeki sapmayı yaklaşık 10-20 pencere boyutunun minimize ettiğini göstermektedir. (Balcılar ve diğerleri, 2010: 1403). Balcılar ve diğerleri 
(2010) çalışmasında da bu çalışmanın gözlem sayısına yakın olan 46 gözlem için 15 sabit pencere boyutu dikkate almıştır.

$\mathrm{Bu}$ alt dönemlere Balcılar ve diğerleri (2010) belirttiği zamana göre değişen Toda-Yamamoto nedensellik testi uygulanmıştır. Yüzde 10 olasılık seviyesinin altında kalan dönemler nedensellik ilișkisinin var olduğu sonucunu göstermektedir. Şekil 1 sonuçlarına göre küresel petrol fiyatlarından diş ticaret açığına doğru nedensellik ilişkisi tespit edilmemiştir. Yani $\mathrm{H}_{0}$ hipotezi olan küresel petrol fiyatları dış ticaret açıklarının Granger nedeni değildir hipotezi hiçbir dönem için reddedilememektedir.

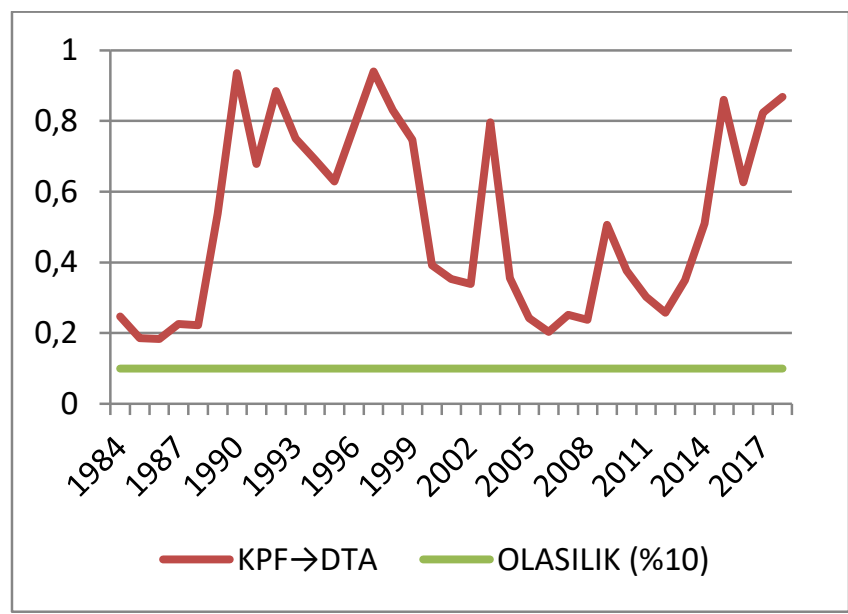

Şekil 1: Zamana Göre Değişen Nedensellik Testi Sonuçları (KPF $\rightarrow$ DTA)

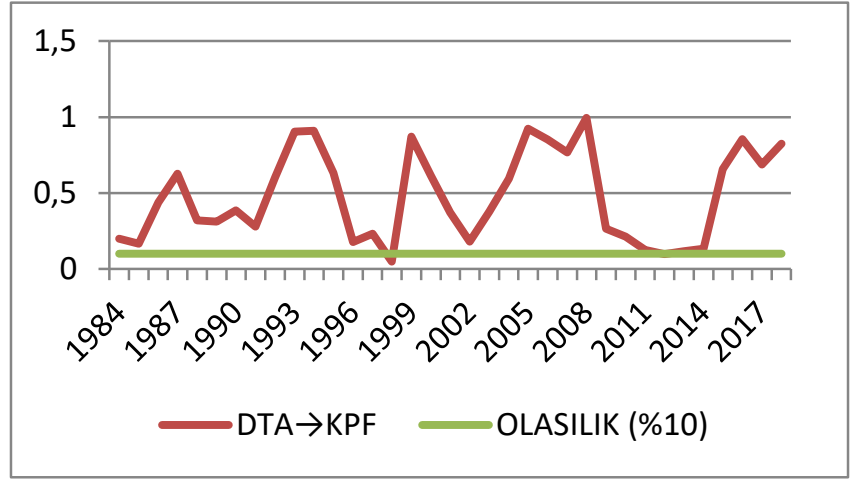

Şekil 2: Zamana Göre Değișen Nedensellik Testi Sonuçları (DTA $\rightarrow$ KPF)

Şekil 2'de ise dış ticaret açıklarından küresel petrol fiyatlarına doğru nedensellik ilişkisi 1998 ve 2012 yıllarında \%10 anlamlılık seviyesinde gerçekleşmektedir. Yani $\mathrm{H}_{0}$ hipotezi olan dış ticaret açıkları küresel petrol fiyatlarının granger nedeni değildir hipotezi 1998 ve 2012 yılları için reddedilebilmektedir.

Zamana göre değișen nedensellik testinde elde edilen bulgulardan Şekil 1'deki sonuç değerlendirildiğinde literatürde verilen Bayar ve diğerleri (2014), Polat (2019) çalışmalarını desteklemektedir. Bir başka ifade ile küresel petrol fiyatlarından dış ticaret açığına doğru nedensellik ilişkisi tespit edilememesi literatürde yer alan sonuçlardandır.

Şekil 2 de ise uzun bir dönem boyunca değil sadece 1998 ve 2012 yılı için diş ticaret açıklarından küresel petrol fiyatlarına doğru nedensellik ilişkisi tespit edilmiştir. 2012 yılı için analizimizde bulunan olasılık değeri 0.09'dur. Şekilde de görüldüğü gibi anlamlılık düzeyi \%5'e indirildiğinde bu anlamlılık kaybolmaktadır. 1998 yılı için ise bulunan olasılık değeri 0.05 dir. \% 5 anlamlılık düzeyinde tam bir sınır değeridir. Türkiye'de 1998 yılında literatürde karşılaşılmayan dış ticaret açıklarından küresel petrol fiyatlarına doğru nedensellik ilişkisi çıkmıştır. Lakin 1998 yılında Rusya krizinin etkisi ile dış ticaretin daraldığı, küresel petrol fiyatlarının 19 dolar seviyelerinden 12 dolar seviyelerine gerilediği \%60 seviyesinde değer kaybının yaşandığı bir dönemdir. Kriz ylları ekonomide dengesizliklere neden olabilmektedir.

\section{SONUC}

$\mathrm{Bu}$ çalışmada, küresel petrol fiyatları ile Türkiye'de dış ticaret açığı arasındaki nedensellik 1969-2018 dönemi için incelenmiş; Hacker ve Hatemi-J (2006) Bootstrap nedensellik testine göre ilişki çıkmamış ve zamana göre değişen nedensellik testine göre küresel petrol fiyatlarından dış ticaret açığına doğru nedensellik ortaya çıkmazken, \% 5 anlamlılık düzeyinde tam tersi yönünde sadece 1998 yılı için nedensellik tespit edilmiştir. Kriz ylllarının ekonomide dengesizliklere neden olduğu görülebilir.

$\mathrm{Bu}$ sonuçlar çerçevesinde incelenen dönemin tamamı söz konusu olduğunda, diş ticaret açıkları ile küresel petrol fiyatları arasında nedensellik ilişkisinin olmadığı görülmektedir. 
Başka bir ifade ile, petrol fiyatları Türkiye'de ticaret dengesinin davranışını etkilememektedir.

Bu sonuçlar; Türkiye'nin görece petrole bağımlı bir ekonomi olmaktan kurtulmaya çalıștığını, en azından küresel petrol fiyatları dişındaki faktörlerin dış ticaret açıklarını etkilediğini belirtmektedir. Çünkü Türkiye'de petrolden kaynaklanan maliyetlerin iç piyasaya yansıtıldığı düşünülmektedir.

$\mathrm{Bu}$ sonuçlara göre, Türkiye'nin büyük çapta enerji talebinin olduğu endüstrilerde enerji tasarrufu sağlayacak politikaları benimsemesi gerektiği belirtilebilir. Bu çerçevede özellikle sanayi kesiminde alternatif enerji üretimi (güneş, rüzgar vb.) kullanılmalı, elektrik ile çalışan otomobil üretimi çalışmalarına hız kazandırılmalı, toplumda bireysel enerji tüketimini minimize edecek bilinç sağlanmalıdır. Bu konu ile ilgili ilerde yapılacak çalıșmalarda, özellikle zamana göre değișen asimetrik nedensellik testleri ile bu nedensellik ilişkisinin şoklar altında nasıl çalıştığının gözlenmesi, literatürdeki bu eksikliğin giderilmesi açısından önemli görülmektedir.

\section{KAYNAKÇA}

Abuoliem, N., Nor, S.M., Matar, A. ve Hallahan, T. (2019). Crude Oil Prices, Macroeconomic Indicators and the Financial Sector in Jordan: Dynamic Causes and Responses. Journal of International Studies, 12(3), 131-146.

Açikalin, S. ve Uğurlu, E. (2014). Oil Price Fluctuations and Trade Balance of Turkey. Proceedings of the International Conference on Economic Sciences and Business Administration, 1(1), 6-13.

Afşar, B., Cura, F. ve Mıhoğlu, A.H. (2019). Petrol Fiyatları İle Cari Açık İlişkisi: Brıc Ülkeleri Ve Türkiye Karşılaştırması. Uluslararası Ekonomi ve Siyaset Bilimleri Akademik Araştırmalar Dergisi, 3(7), 1-12.

Balcilar, M., Özdemir, Z. A. ve Arslantürk, Y. (2010). Economic Growth and Energy Consumption Causal Nexus Viewed Through A Bootstrap Rolling Window. Energy Economics, 32(6), 1398-1410.

Başarir, Ç. ve Erçakar, M.E. (2016). An Analysis Of The Relationship Between Crude Oil Prices, Current Account Deficit And Exchange Rates: Turkish Experiment. International Journal of Economics and Finance, 8(11), 48-59.

Bayar, Y., Kılıç, C. ve Arıca, F. (2014). Türkiye'de Cari Açığın Belirleyicileri. C.Ü. İktisadi ve İdari Bilimler Dergisi, 15(1), 451-471.
Bayar, Y. ve Karamelikli, H. (2015). Impact of Oil And Natural Gas Prices On The Turkısh Foreign Trade Balance: Unit Root And Co-integration Tests With Structural Breaks. Romanian Economic and Business Review, 10 (3), 91-104.

Bayat, T., Şahbaz, A. ve Akçaci, T. (2013). Petrol Fiyatlarının Dış Ticaret Açı̆̆ Üzerindeki Etkisi: Türkiye Örneği. Erciyes Üniversitesi İktisadi ve İdari Bilimler Fakültesi Dergisi, 42, 67-90.

Bayraktar, Y., Eğri, T. ve Yıldız, F. (2016). A Causal Relationship Between Oil Prices Current Account Deficit, And Economic Growth: An Empirical Analysis from Fragile Five Countries. Eco forum Journal, 5(3), 29-44.

Bernanke, B.S., Gertler, M. ve Watson, M. (1997). Systematic Monetary Policy And The Effects Of Oil Price Shocks. Brookings Papers on Economic Activity, 1, 91-142.

Beşel, F. (2017). Oil Prices Affect Current Account Deficit: Empirical Evidence From Turkey. Journal of Applied Research in Finance and Economics, 3(2), 13-21.

Bhatta, G. R. (2013). Remittance and Trade Deficit Nexus in Nepal: A VECM Approach. NRB Economic Review, 25(1), 37-50.

Boman, V. (2019). The Impact from Oil Price Shocks on the Trade Balance: The Case of the Two Nordic Brothers (Unpublished Master's 
Thesis). Umea University Economics Program Umea/Sweden.

Bozgeyik, Y. ve Kutlu, A. (2019). Türkiye'de Cari Açı̆̆ın Belirleyicileri: 1992-2017 Dönemi İçin Ampirik Çalışma. Maliye Dergisi, 176,1-26.

Değirmen, S. ve Saltık, O. (2017). Impacts Of Realized Volatility of Oil Price Over Foreign Trade Related Activities İn Turkey. Economic Change and Restructuring, 50(3), 193-209.

Demir, M.A. (2019). Uluslararası Enerji Fiyatlarının Dünya Ticareti Üzerine Etkisi. Yayınlanmamış doktora tezi, Dokuz Eylül Üniversitesi Sosyal Bilimler Enstitüsü, İzmir.

Dickey, D. A. ve Fuller, W. A. (1981). Likelihood Ratio Statistics For Autoregressive Time Series With A Unit Root. Econometrica: Journal of the Econometric Society, 49(4), 1057-1072.

Doğan, İ. ve Gürbüz, S. (2017). Enerji Fiyatlarının Dış Ticaret Açığı Üzerindeki Rolü: Doğrusal Olmayan İlişkinin Analizi. Ömer Halisdemir Üniversitesi İktisadi ve İdari Bilimler Fakültesi Dergisi,10(2), 81-90.

Erdoğan, S. ve Bozkurt, H. (2009). Türkiye'de Cari Açığın Belirleyicileri: MGARCH Modelleri İle Bir İnceleme. Maliye ve Finans Yazıları, 1(84), 135-172.

Göçer, Ş., Deniz, M. B. ve Bursal, M. (2019). Türkiye'de Dış Ticaret Hadlerinin Altın, Gümüş, Dolar, Petrol Ve Doğalgaz Fiyatları İle İlișkisi: Eş Bütünleşme Analizi. Bartın Üniversitesi İktisadi ve İdari Bilimler Fakültesi Dergisi, 10(20), 191203.

Granger, C.W.J., (1996). Can We Improve the Perceived Quality of Economic Forecasts? Journal of Applied Econometrics, 11, 455-473.

Güngör, S., Sönmez, L., Korkmaz, Ö. ve Karaca, S. S. (2016). Petrol Fiyatlarındaki Değişimlerin Türkiye'nin Cari İşlemler Açığına Etkileri. Maliye Finans Yazıları, 106, 29-48.

Hacker, R. S. ve Hatemi-J, A. (2006). Tests For Causality Between İntegrated Variables Using Asymptotic And Bootstrap Distributions: Theory And Application. Applied Economics, 38(13), 1489-1500.
İnsel, A. ve Kayikçi, F. (2013). Determinants Of The Current Account Balance İn Turkey: An Ardl Approach. Economic research-Ekonomska istraživanja, 26(1), 1-16.

Kadooğlu Aydın, G. (2017). Ödemeler Dengesi Ve Cari Açık: Türkiye'de 2014-2016 Yılları Arasında Cari Açık Ve Petrol Fiyatları Etkileșimi. Fırat Üniversitesi Uluslararası İktisadi ve İdari Bilimler Dergisi, 1(2), 27-66.

Karadaș, H.A., Salihoğlu,E. ve Koşaroğlu, Ş.M. (2019). Current Account Deficit Problem İn Turkish Economy: An Application With Selected Macroeconomic Variables. Bilecik Şeyh Edebali University Journal of Social Sciences Institute,4(1), 448-461.

Karagöl, V. ve Kırca, M. (2019). G-7 Ülkelerinde Petrol Fiyatları Ve Cari İşlemler Dengesi Arasındaki Simetrik Ve Asimetrik Nedensellik İlişkilerinin Analizi. Proceedings of the EconWorld2019@Budapest, 1-14.

Kırca, M. ve Karagöl, V. (2019). Symmetric And Asymmetric Causality Between Current Account Balance And Oil Prices: The Case of BRICS-T. Applied Econometrics, 56, 25-44.

Knight, D., Nedeljkovic, M. ve Portugal-Perez, A. (2019). Turkey: An Empirical Assessment of The Determinants of The Current Account Balance. (Policy Research Working Paper No. 8982) The World Bank.

Kolçak,M., Kalabak, A,Y. ve Boran,H. (2017). Kamu Harcamaları Büyüme Üzerinde Bir Politika Aracı Olarak Kullanılmalı mı? VECM Analizi ve Yapısal Kırılma Testleri ile Ampirik Bir Analiz: 1984-2014 Türkiye Örneği. Ankara Üniversitesi Siyasal Bilgiler Fakültesi Dergisi, 72(2), 467-486.

Kunle, A.S. (2020). Oil Price Volatility and Trade Balance: Co-integration and Causality Analysis in Nigeria. International Journal of Scientific and Management Research, 3(1), 24-30.

Le, T-H.ve Chang,Y. (2013). Oil Price Shocks and Trade Imbalances. Energy Economics, 36, 7896. 


\section{M.A. DEMIR}

Lebe, F. ve Akbaș, Y. (2015). İthal Ham Petrol Fiyatları İle Döviz Kurunun Cari Açık Üzerindeki Etkisi: Türkiye İçin Bir Araştırma. Gazi Üniversitesi İktisadi ve İdari Bilimler Fakültesi Dergisi, 17 (2), 170-196.

Lee, J. ve Strazicich, M. C. (2003). Minimum Lagrange Multiplier Unit Root Test with Two Structural Breaks. Review of Economics and Statistics, 85(4), 1082-1089.

Olayungbo, D.O. (2019). Effects of Global Oil Price on Exchange Rate, Trade Balance, and Reserves in Nigeria: A Frequency Domain Causality Approach. Journal of Risk and Financial Management, 12(43), 1-14.

Özlale, Ü. ve Pekkurnaz, D. (2010). Oil Prices And Current Account: A Structural Analysis For The Turkish Economy. Energy Policy, 38(8), 4489-4496.

Pesaran, M. H. ve Timmermann, A. (2005). Small Sample Properties of Forecasts From Autoregressive Models Under Structural Breaks. Journal of Econometrics, 129(1-2), 183-217.

Phillips, P. C. ve Perron, P. (1988). Testing For A Unit Root İn Time Series Regression. Biometrika, 75(2),335-346.

Polat, M.A. (2019). Petrol Fiyatlarının ve Reel Efektif Döviz Kurunun Türkiye'nin Dış Ticaret Dengesine Etkileri: Sınır Testi Yaklaşımı. Maliye ve Finans Yazıları, 112, 149-174.
Rafiq, S.,Salim, R. ve Bloch, H. (2009). Impact of Crude Oil Price Volatility on Economic Activities: An Empirical Investigation in the Thai Economy. Resources Policy, 34, 121-132.

Terzi, N. ve Çelik, S. (2016). Oil Prices And Trade İn Turkey: A Wavelet Continuous Transform Analysis. Eurasian Journal of Economics and Finance, 4(4), 29-41.

Tiwari, A.K. , AROURİ, M. ve Teulon,F. (2014). Oil Prices and Trade Balance: A Frequency Domain Analysis for India. Economics Bulletin, 34(2), 663-680.

Toda, H. Y. ve Yamamoto, T. (1995). Statistical Inference in Vector Autoregressions with Possibly Integrated Processes. Journal of Econometrics, 66(1-2), 225-250.

Unutur, P.K. (2018). The Effect of Crude Oil Prices on the Foreign Trade Deficit - Case of Turkey (2000-2015). (Unpublished Master's Thesis). Dogus University Institute of Social Science, İstanbul.

Yılmaz,S. ve Bugay Tekgül, Y. (2019). Türkiye'de Döviz Kuru Politikalarının Olası Etkileri. Çukurova Üniversitesi Sosyal Bilimler Enstitüsü Dergisi , 28(3), 170-181.

Yılmaz, H. ve Tütüncü, A.(2020). Türkiye'de Bütçe Açı̆̆ı-Cari Açık İlișkisi: Zamanla Değișen Nedensellik Testi (1975-2017). Eskișehir Osmangazi Üniversitesi İktisadi ve İdari Bilimler Dergisi, 15(1), 47-60. 